\title{
Historical Land Use/Cover Changes and the Hemeroby Levels of a Bio-Cultural Landscape: Past, Present and Future
}

\author{
Angela Terumi Fushita1, José Eduardo dos Santos², Yuri Tavares Rocha ${ }^{3}$, Elisabete Maria Zanin ${ }^{4}$ \\ ${ }^{1}$ Center of Engineering, Modeling and Applied Social Sciences, Universidade Federal do ABC (UFABC), Santo André, Brazil \\ ${ }^{2}$ Pos-Graduate Programme in Ecology and Natural Resources, Universidade Federal de São Carlos (UFSCar), São Carlos, Brazil \\ ${ }^{3}$ Department of Geography, Universidade de São Paulo (USP), São Paulo, Brazil \\ ${ }^{4}$ Department of Biological Science, Universidade Regional Integrada do Alto Uruguai e das Missões (URI), Erechim, Brazil \\ Email: angela.fushita@ufabc.edu.br,djes@ufscar.br, yuritr@usp.br, emz@uri.com.br
}

How to cite this paper: Fushita, A.T., dos Santos, J.E., Rocha, Y.T. and Zanin, E.M. (2017) Historical Land Use/Cover Changes and the Hemeroby Levels of a Bio-Cultural Landscape: Past, Present and Future. Journal of Geographic Information System, 9, 576-590.

https://doi.org/10.4236/jgis.2017.95036

Received: August 22, 2017

Accepted: September 27, 2017

Published: September 30, 2017

Copyright $\odot 2017$ by authors and Scientific Research Publishing Inc. This work is licensed under the Creative Commons Attribution International License (CC BY 4.0).

http://creativecommons.org/licenses/by/4.0/

\section{Abstract}

The urbanization of a campus landscape has required much space for this expansion, reinforcing the status of geographical space as a limited resource. We analyzed the effects of land cover change assessed over temporal dataset on composition and configuration dynamics of UFSCar (Federal University of São Carlos) campus landscape, based on a descriptive view of the hemeroby levels, over a 54-year period (1962-2016), in order to understand the impacts of past anthropogenic induced landscape change and inform decision making with regard to biodiversity management. The classification of land use/cover dynamics, over time, was obtained based on screen digitizing of aerial photos and LandSat imagery. An ordinal scale ranging from ahemerob to metahemerob was applied to assess the hemerobiotic state of each land use type. Currently, The UFSCar landscape campus configures a biocultural mosaic in different stages of hemeroby. Thus a campus landscape dynamics model, which can be denoted as "forestry-conservation-urban model", anthropogenic landscape is replaced by natural one, later by land cover reflecting the spatial anthropization process. Through time, two hemerobiotic trajectories were identified, in which 1) an euhemerob landscape matrix is substituted by an ahemerob one, resulting in increased naturalness of the campus landscape, and then 2) metahemerob patch types will later on increasing as a consequence of ongoing urbanization. Expressive amount of ahemerob patches in campus landscape fulfills one of the conditions for maintenance of the capacity for self-regulation and sustainability of a biocultural landscape. This framework provides an essential tool supporting with essential information about current and historical landscape sustainability for campus landscape 
management and support decision making process. The main institutional challenge for campus landscape sustainable management lies in the balance between the competitors of the campus landscape matrix: conservation $\mathrm{x}$ urbanization.

\section{Keywords}

Land Use Change Trajectories, Urbanization, Conservation, Landscape Sustainable Management

\section{Introduction}

A landscape can be defined as the level of spatial or biological organization situated between the ecosystem level (lower level of organization than the landscape) and the regional level (higher level of organization than the landscape) [1] [2] [3].

To best describe a landscape, the patch-corridor-matrix model is generally applied, and three types of components are identified [3] [4] [5]. A landscape can therefore also be defined as a mosaic of patches, the latter being considered as the components of pattern [1]. Landscapes are consequently dynamic and are often referred to as shifting mosaics [6].

Human activity affects landscape pattern in rescaling patterns in time and space, or homogenizing patterns through land use [1]. The conversion of native landscapes into anthropogenic ones results in widespread changes in landscape spatial patterns [7]. Two opposite processes can have profound consequences on the structure and functioning landscape. They are: 1) intensification of agriculture and urbanization and 2) the abandonment of land [8].

Since anthropogenic activity began to use and shape the land, their influence has kept on growing so that currently, little or no landscape is considered as untouched [9] [10]. For this reason, most landscapes are now being referred to as biocultural landscapes: generated by both natural and anthropogenic processes, but characterized by anthropogenic pattern features, of which the measurement constitutes a key step in landscape analysis [11].

Metrics and strategies for measurement anthropogenic patterns and their dynamics are discussed considering the pattern/process paradigm, the patch - corridor-matrix model and the complementary of landscape composition and configuration, as conceptual benchmarks [11] [12].

There is a growing demand for environmental indicators to measure and evaluate land use related anthropogenic influence on landscape patterns and processes [13] [14] [15] [16] [17]. These tools also showcase the dynamics of decreasing naturalness or increasing artificiality resulting from anthropic activities to be monitored in time and space. They also provide essential information about current and historical landscape pattern for regional and local management and support decision making processes [18]. 
The concept of hemeroby was applied to describe gradients of human influence on landscape [19]. Later it was extended by integrating parameters that describe human impacts resulting from land use types [20], with a complementary meaning to that of naturalness [21]. Many attempts have been made to define naturalness and attribute degrees of naturalness to ecosystems and landscapes [22]-[27]. Although the conceptual relationship between hemeroby and naturalness varies in the literature, most researchers agree that they are opposite extremes of a continuous gradient [27].

Data on hemeroby are given on a several ordinal scales to evaluate the effects of different landscape patterns use [21]. The hemeroby ordinal scales range from four points [19] to seven points extended scales, as a measure of anthropogenic interference related mainly to land use [17] [18] [19] [28] [29]. Ahemerob landscapes are those with a self-regulating capacity, without actual human impact, while metahemerob landscapes are those created intentionally by human activity, characterized by the intense dominance of structures and technological processes and with reduced self-regulation capacity [30].

This work presents an empirical analysis of the land use influence on the composition and configuration dynamics of a biocultural landscape, based on a descriptive view of the hemeroby levels in a campus landscape, over a 54-year period (1962-2016). The analysis of the hemeroby level changes, over time, provides an essential tool supported with essential information about current and historical landscape sustainability for campus landscape management and support decision making process.

\section{Material and Methods}

\section{The Campus Environment}

The creation of the UFSCar was formalized in 1968. The area of the former Trancham Farm, with an extension of 677.546 ha, was expropriated by the $\mathrm{Mu}$ nicipal Government of São Carlos, and donated to the UFSCar campus installation [31].

The campus landscape of the Federal University of São Carlos (UFSCar) is very fortunate to be located in the advanced city of São Carlos, SP, Brazil (Figure 1 ), with a compact and walkable campus located away from the centre of town, with many old and innovative new buildings, and a diverse landscape that has evolved over time and become an integral part of the urban area of the city. The campus landscape provides an environment that situates, serves and symbolizes higher education. This landscape comprises the lawns, open spaces, gardens, walkways and paths, play fields, parking lots, and various other components of the constructed environment which surround and support the buildings and other facilities on a college campus.

The UFSCar Campus Master Plan has provided the University with the opportunity to re-think the management of the campus grounds to date and plan for a redevelopment of the natural and man-made landscape that is more 

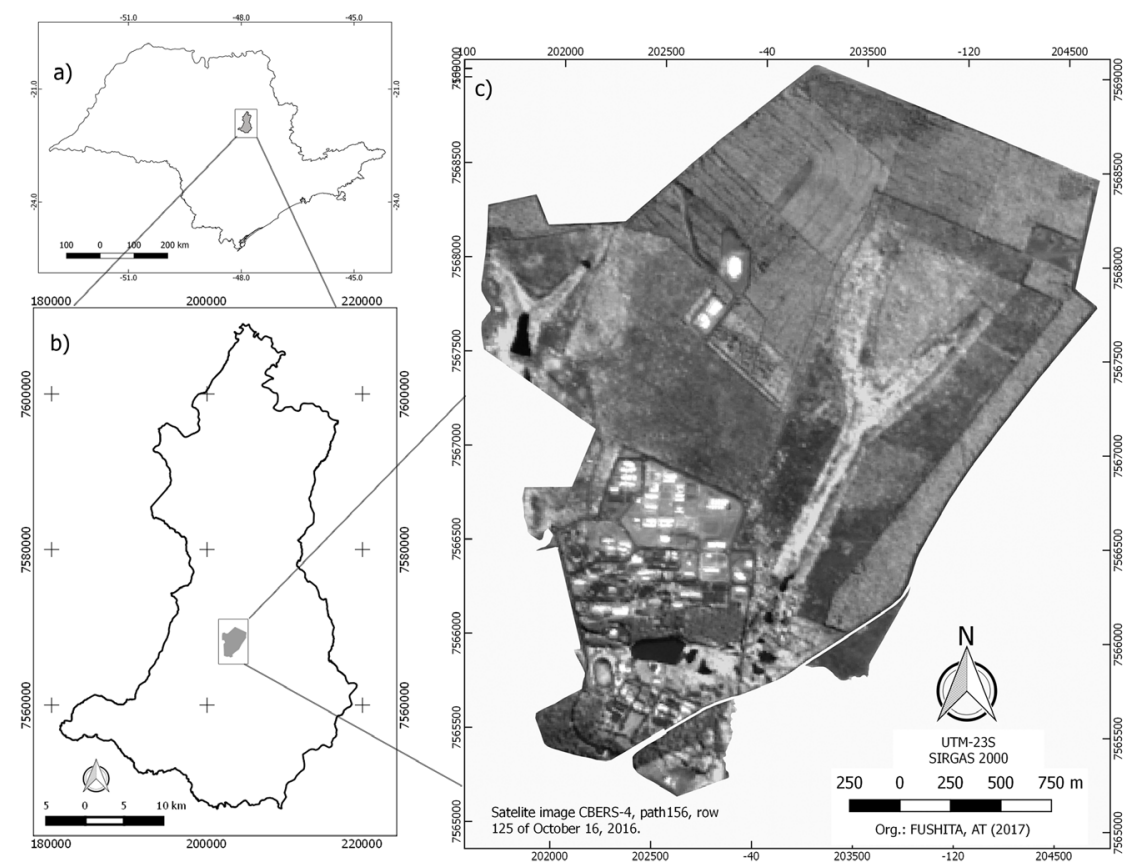

Figure 1. Location and land use/cover of the campus landscape of the Federal University of São Carlos (c); São Carlos Municipality (b); São Paulo state (a).

user-friendly and welcoming, and gives a better representative of the original biodiversity of São Carlos. There is always opportunity for improvement; and the University is dedicated to including sustainable principles in the campus landscape management. It has become increasingly more important to the emotional and economic wellbeing of this institution that presents an attractive and well-maintained facade.

The classification of land use/cover dynamics, over a 54-year period (19622016), was obtained based on screen digitizing of aerial photos (1962 and 1972, Technical Collection LASERE-USP; 1988, Technical CollectionTerraFoto; 1997, Technical Collection LAPA-UFSCar), and LandSat imagery (2009, CBERS-2, sensor HRC, Band 1, and 2016, CBERS-4, sensor PAN).

The land use typology were discriminated by the criteria of tone, texture and context [32] [33], through polygon manual digitalization in ArcMap 10.2 software, based on georeferenced images in the Universal Transversal Mercator (UTM) projection, SIRGAS datum, 23S spindle. Each polygon of land use/cover was related to a previously hierarchical level of land use class [34] [35].

An ordinal scale ranging from level 1 (ahemerob; i.e., natural vegetation unchanged by human influence) to level 7 (metahemerob; i.e., artificial landscape elements that do not resemble the natural vegetation) was applied to assess the hemerobiotic state of each land use type of the campus landscape. The ordinal scale is referenced to anthropogenic interference mainly related to land use [18] [20] [28] [36]. The hemerobiotic state of each land use type was assigned based on expert judgment and the experience of an extensive campus landscape field survey. 


\section{Results and Discussion}

The campus landscape pattern, over a 54-year period (1962-2016), is determined by the presence of 4 (four) land use classes (Figure 2), and by their proportional presence (Table 1), later categorized into 10 (ten) land cover types: 1) Natural (Cerrado vegetation and riparian forest, and São Carlos Ecological Park); 2) Anthropogenic agricultural (forestry and pasture); 3) Anthropogenic nonagricultural (urban area and road net); and 4) Aquatic environment (river, lakes, and reservoirs).

This land use/cover series (Figure 2) is related to typical changes in campus landscape and biological characteristics during the conversion and replacement of a land use type by another type, expressing the range of human effects on landscape in terms of the prevalent land use, and applying four levels: utilization of components of the system (e.g. forestry and pasture, 1962); replacement of one land use type by another type (1972-2016); conservation of unmodified system (Cerrado vegetation, riparian forest, and São Carlos Ecological Park, 19882016), and human-dominated landscape complete destruction (eg. Urbanization, 1972-2016) (Figure 2 and Table 1).
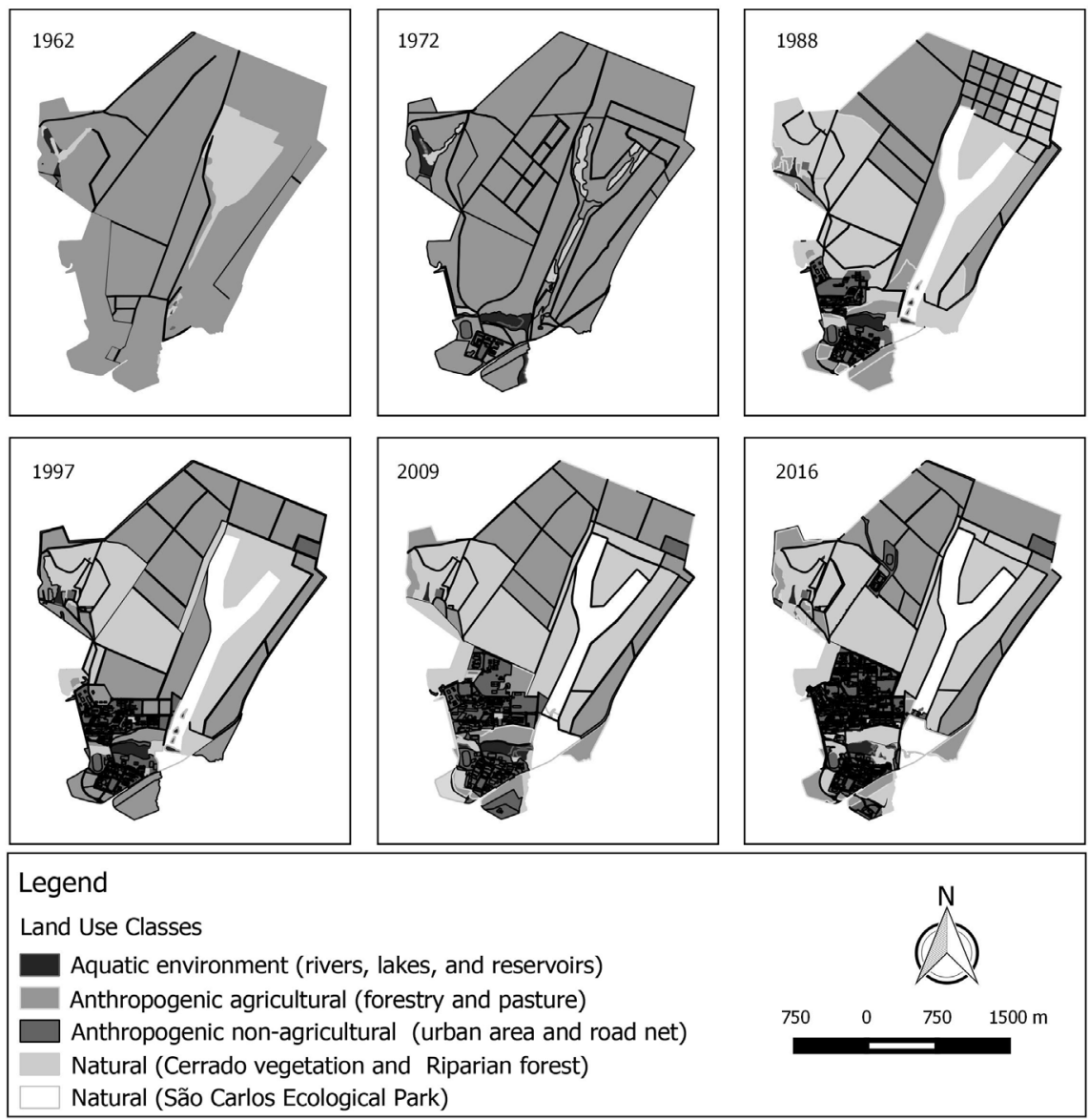

Aquatic environment (rivers, lakes, and reservoirs) Anthropogenic agricultural (forestry and pasture) Anthropogenic non-agricultural (urban area and road net) Natural (Cerrado vegetation and Riparian forest) Natural (São Carlos Ecological Park)

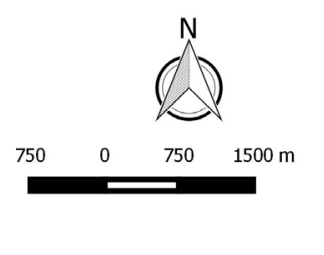

Figure 2. Spatial trajectory of land use classes in the campus landscape of the Federal University of São Carlos (São Carlos, SP), at a primary hierarchical classification level, over a 54-year period (1962-2016). 
Table 1. Area occupied (ha and \%) by the land use classes in the landscape campus of the Federal University of São Carlos (São Carlos, SP), at a primary hierarchical classification level, over a 54-year period (1962-2016).

\begin{tabular}{|c|c|c|c|c|c|c|c|}
\hline \multirow{3}{*}{ 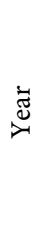 } & \multirow{3}{*}{ Area } & \multicolumn{6}{|c|}{ Land Use Classes } \\
\hline & & \multirow[b]{2}{*}{$\begin{array}{c}\text { Aquatic environment } \\
\text { (rivers, lakes, and reservoirs) }\end{array}$} & \multicolumn{2}{|c|}{ Anthropogenic } & \multicolumn{2}{|c|}{ Natural } & \multirow[b]{2}{*}{ Total } \\
\hline & & & $\begin{array}{c}\text { Anthropogenic } \\
\text { agricultural } \\
\text { (forestry and pasture) }\end{array}$ & $\begin{array}{c}\text { Anthropogenic } \\
\text { non-agricultural } \\
\text { (urban area and road net) }\end{array}$ & $\begin{array}{c}\text { Cerrado } \\
\text { vegetation and } \\
\text { Riparian forest }\end{array}$ & $\begin{array}{l}\text { São Carlos } \\
\text { Ecological } \\
\text { Park }\end{array}$ & \\
\hline \multirow{2}{*}{$\begin{array}{l}\text { ָे } \\
ٌ\end{array}$} & ha & 4.03 & 614.77 & 19.21 & 67.7 & - & 705.71 \\
\hline & $\%$ & 0.57 & 87.11 & 2.72 & 9.59 & - & 100.00 \\
\hline \multirow{2}{*}{$\underset{\widehat{N}}{\stackrel{N}{a}}$} & ha & 14.65 & 633.64 & 35.80 & 21.62 & - & 705.71 \\
\hline & $\%$ & 2.08 & 89.79 & 5.07 & 3.06 & - & 100.00 \\
\hline \multirow{2}{*}{ 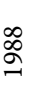 } & ha & 7.91 & 257.60 & 80.00 & 292.31 & 67.89 & 705.71 \\
\hline & $\%$ & 1.12 & 36.50 & 11.34 & 41.42 & 9.62 & 100.00 \\
\hline \multirow{2}{*}{ ลू } & ha & 7.91 & 319.37 & 97.30 & 213.25 & 67.88 & 705.71 \\
\hline & $\%$ & 1.12 & 45.26 & 13.79 & 30.22 & 9.62 & 100.00 \\
\hline \multirow{2}{*}{ ஓे̀ } & ha & 8.66 & 254.53 & 126.80 & 247.83 & 67.89 & 705.71 \\
\hline & $\%$ & 1.23 & 36.07 & 17.97 & 35.12 & 9.62 & 100.00 \\
\hline \multirow{2}{*}{$\begin{array}{l}0 \\
\stackrel{\sim}{\sim}\end{array}$} & ha & 7.73 & 226.64 & 135.26 & 268.19 & 67.89 & 705.71 \\
\hline & $\%$ & 1.1 & 32.11 & 19.17 & 38.00 & 9.62 & 100.00 \\
\hline
\end{tabular}

The landscape pattern component denoted as landscape composition (Figure 2), shows a transition related to the following reduction of the forestry areas (from $87.11 \%$ to $32.11 \%$ ), to support urbanization increase (2.72\% to $19.16 \%$ ), and the increase of the natural land use area (9.59\% to $47.62 \%)$, over the 54 -year period (1962-2016) (Table 1).

The campus landscape was predominantly occupied by anthropogenic agricultural use in 1962 (Figure 2; Table 1). In 1969, the campus landscape (Trancham Farm) was described "as a virtually degraded and unproductive landscape. In addition to more than 1 million of eucalyptus trees, unproductive coffee and citrus plantations, and a fantastic quantity of ants, it had many old and degraded buildings needing significant renovations. The eucalyptus forests are unproductive, damaged by fire and badly made cuts. Pastures with many invasive species are depleted by livestock (Process of the Trancham Farm Disapropriation, 1969). In 2016, the campus landscape composition interpretation is still being referred to as anthropogenic prevailing land use, after a 54-year period (1962-2016) (Figure 2; Table 1).

The increase in natural land use, over the 28-year period, resulted from the: 1). Implementation of the Ecological Park of São Carlos; 2). The registration of three legal reserve areas totaling 174.84 ha, equivalent to $24.77 \%$ of the total campus landscape area; 3 ). The recovery of the remaining Cerrado vegetation area, totaling $47.71 \mathrm{ha}$. The continuity of this Cerrado vegetation area in campus landscape is ensured by legal devices that prevent any damages or deforestation 
for this type of phytophysiognomy, with this area becoming a preventive factor to the urbanization advance on the South-North transect of the campus landscape (Figure 2, 1988-2016).

The São Carlos Ecological Park, inserted in the limits of the campus landscape (Figure 2), was created in 1976, and comprises an area of 67.89 ha, occupied by Cerrado vegetation and riparian forest, as well as an area occupied by the Espraiado stream. It is administered by the Municipal Public Services Department of the Municipality of São Carlos, having as main objective the conservation of regional biodiversity related to South American fauna.

The lotic environments of the campus landscape are: (i) the Fazzari stream whose source is located inside the campus, being a tributary of the Monjolinho river, (ii) the Espraiado stream, which together with the riparian forest make up the Park Ecological of São Carlos, and (iii) Monjolinho river, which downstream of the campus landscape drains the urban area of the São Carlos municipality. The lengths of these streams at the campus boundaries correspond, respectively to: $437.5,877.2$, and $571.4 \mathrm{~m}$.

The Fazzari reservoir, the Mayacalake, and the Monjolinho reservoir make up the campus's lentic environments; together with ABASC reservoir, which has only a part of its area located in campus landscape limits. The three lentic systems occupy about $0.90 \%$ of the total campus landscape area, with the Monjolinho reservoir occupying an area of $4.69 \mathrm{ha}$, the Mayacalake with $0.15 \mathrm{ha}$, and the Fazzari lake with 1.22 ha.

In order to quantify campus landscape spatial pattern, 4 levels of hemeroby were categorized: ahemerob (natural patches without or a minimal anthropogenic interference), oligohemerob (natural patches with anthropogenic influence), euhemerob (patches created intentionally by human activity with reduced self-regulation capacity), and metahemerob (dominance of structures and technological processes and with reduced self-regulation capacity) (Figure 3 ). The values of occupied area by each hemeroby level of the campus landscape over a 54-year period are represented in Table 2 (1962-2016).

Through time, a sequence of campus landscape dynamics with two hemerobiotic trajectories were identified, in which 1) an euhemerob landscape matrix is substituted by an ahemerob one (Figure 4; Table 2), resulting in increased naturalness of the campus landscape, and then 2) metahemerob patch types will later on increase as a consequence of ongoing urbanization (Figure 5; Table 2), over a 54-year period (1962-2016).

In the current contribution, the cultural component of campus landscape may be generalized to the spatial anthropization process, which refers to agriculture/ forestry, built structures, road infrastructure or any other substitution or alteration of different land cover type by an anthropogenic type.

The trajectory of anthropogenic influence on the campus landscape is associated with euhemerob to metahemerob patches transition caused by patches creation, enlargement, and aggregation resulting from campus landscape urbanization, from 1972 (Figure 3 and Figure 5). The expansion of the metaheme- 


\begin{tabular}{|c|c|c|}
\hline $\begin{array}{l}\text { Ordinal scale } \\
\text { of hemeroby } \\
\text { levels }\end{array}$ & Description of land/cover use & $\begin{array}{l}\text { Photos of the land use types on } \\
\text { campus landscape related to the } \\
\text { hemeroby levels }\end{array}$ \\
\hline Ahemerob & $\begin{array}{l}\text { Patches of Cerrado vegetation and } \\
\text { riparian forest. Reservoirs with } \\
\text { minimal anthropogenic interference } \\
\text { were also included in this category. }\end{array}$ & \\
\hline Oligohemerob & $\begin{array}{l}\text { Patches of Cerrado vegetation in } \\
\text { regeneration, and water bodies } \\
\text { with anthropic influence. }\end{array}$ & \\
\hline Mesohemerob & $\begin{array}{l}\text { Not identified in the campus } \\
\text { landscape }\end{array}$ & \\
\hline Euhemerob & $\begin{array}{l}\text { Forestry areas (eucalyptus) and } \\
\text { bare soil. }\end{array}$ & \\
\hline Polihemerob & $\begin{array}{l}\text { Not identified in the campus } \\
\text { landscape }\end{array}$ & \\
\hline Metahemerob & $\begin{array}{l}\text { Urbanized area with the presence } \\
\text { of artificial landscape components } \\
\text { (buildings, gardens, and other non- } \\
\text { waterproofed surfaces). Few } \\
\text { arboreal individuals and } \\
\text { herbaceous vegetation and } \\
\text { compacted and waterproofed soils. }\end{array}$ & \\
\hline
\end{tabular}

Figure 3. Ordinal scale of hemeroby to assess the hemerobiotic state of land use types of the campus landscape of the Federal University of São Carlos (São Carlos, SP). Adaptedby [18] [20] [25] and [30].

Table 2. Area (ha and \%) of the hemeroby levels of the campus landscape of the Federal University of São Carlos (São Carlos, SP), over a 54-year period (1962-2016).

\begin{tabular}{|c|c|c|c|c|c|c|}
\hline \multirow{2}{*}{ 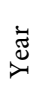 } & \multirow{2}{*}{ Area } & \multicolumn{5}{|c|}{ Hemeroby level types } \\
\hline & & Ahemerob & Oligohemerob & Euhemerob & Metahemerob & Total \\
\hline \multirow{2}{*}{ ర్రి } & ha & 68.91 & 2.88 & 633.19 & 0.73 & 705.71 \\
\hline & $\%$ & 9.76 & 0.41 & 89.72 & 0.10 & 100.00 \\
\hline \multirow{2}{*}{$\stackrel{N}{\sigma}$} & ha & 26.36 & 9.70 & 663.20 & 6.45 & 705.71 \\
\hline & $\%$ & 3.74 & 1.37 & 93.98 & 0.91 & 100.00 \\
\hline \multirow{2}{*}{$\begin{array}{l}\infty \\
\stackrel{\infty}{二}\end{array}$} & ha & 293.97 & 73.93 & 287.72 & 50.09 & 705.71 \\
\hline & $\%$ & 41.66 & 10.48 & 40.78 & 7.10 & 100.00 \\
\hline \multirow{2}{*}{ 亏ิ } & ha & 204.87 & 85.28 & 354.93 & 60.63 & 705.71 \\
\hline & $\%$ & 29.03 & 12.08 & 50.29 & 8.59 & 100.00 \\
\hline \multirow{2}{*}{ ஓे } & ha & 319.29 & 6.15 & 281.95 & 98.32 & 705.71 \\
\hline & $\%$ & 45.24 & 0.87 & 39.95 & 13.93 & 100.00 \\
\hline \multirow{2}{*}{ 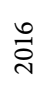 } & ha & 326.16 & 18.14 & 258.79 & 102.62 & 705.71 \\
\hline & $\%$ & 46.22 & 2.57 & 36.67 & 14.54 & 100.00 \\
\hline
\end{tabular}



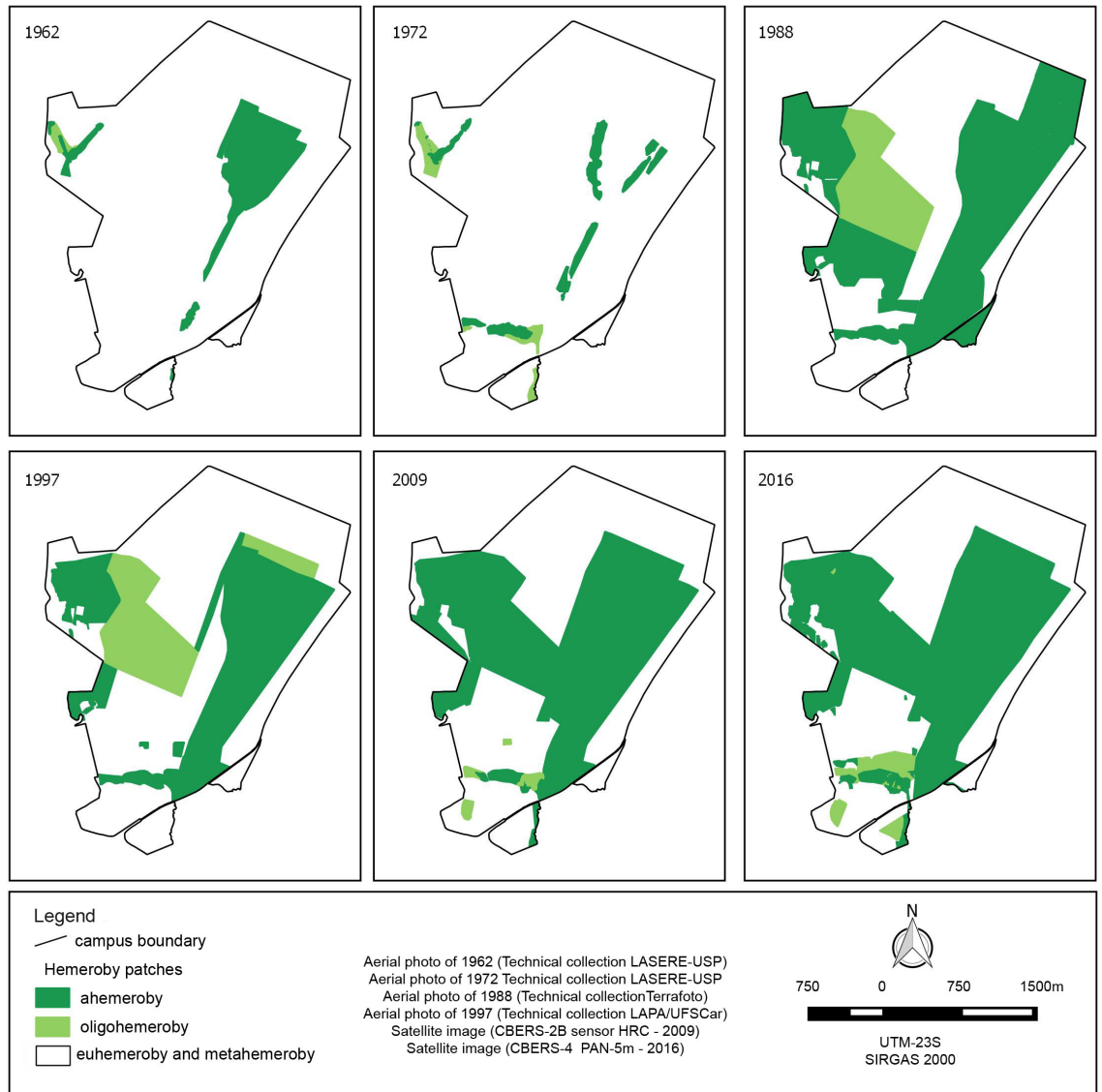

Figure 4. Sequence of campus landscape dynamics in which (1) an anthropogenic landscape matrix is substituted by an ahemerob one, resulting in increased naturalness of the campus landscape, over a 54-year period (1962-2016).

rob patches area has been occurring in the South-North direction of the campus landscape, and from 2016, is limited by the ahemerobic patches area (Figure 5).

Metahemerob patches area in campus landscape has shown rapid enlargement, since 1997. The management of the micro built areas, where natural and urban areas meet and conflict (Figure 5, 1997-2016), announces itself as a key issue for campus landscape management, in the next decades. These micro built areas corresponding to isolated built structures work as link core between other metahemerob patches of the campus landscape.

Landscape geographical space could and should be considered as a limited resource: the use of space by one land use/cover type reduces the remaining space available to other types [12]. Anthropogenic change of campus landscapes confirms the status of geographical space as a limited resource. The campus landscape urbanization development requires much space for this expansion, and must be replaced with euhemeroby patches which are currently occupied by forest (Figure 5).

The spatial pattern referred to as landscape configuration, in 2016, describes a group of hemerob patches of different sizes and shapes scattered across the campus landscape. The campus landscape can be considered quite heterogene- 

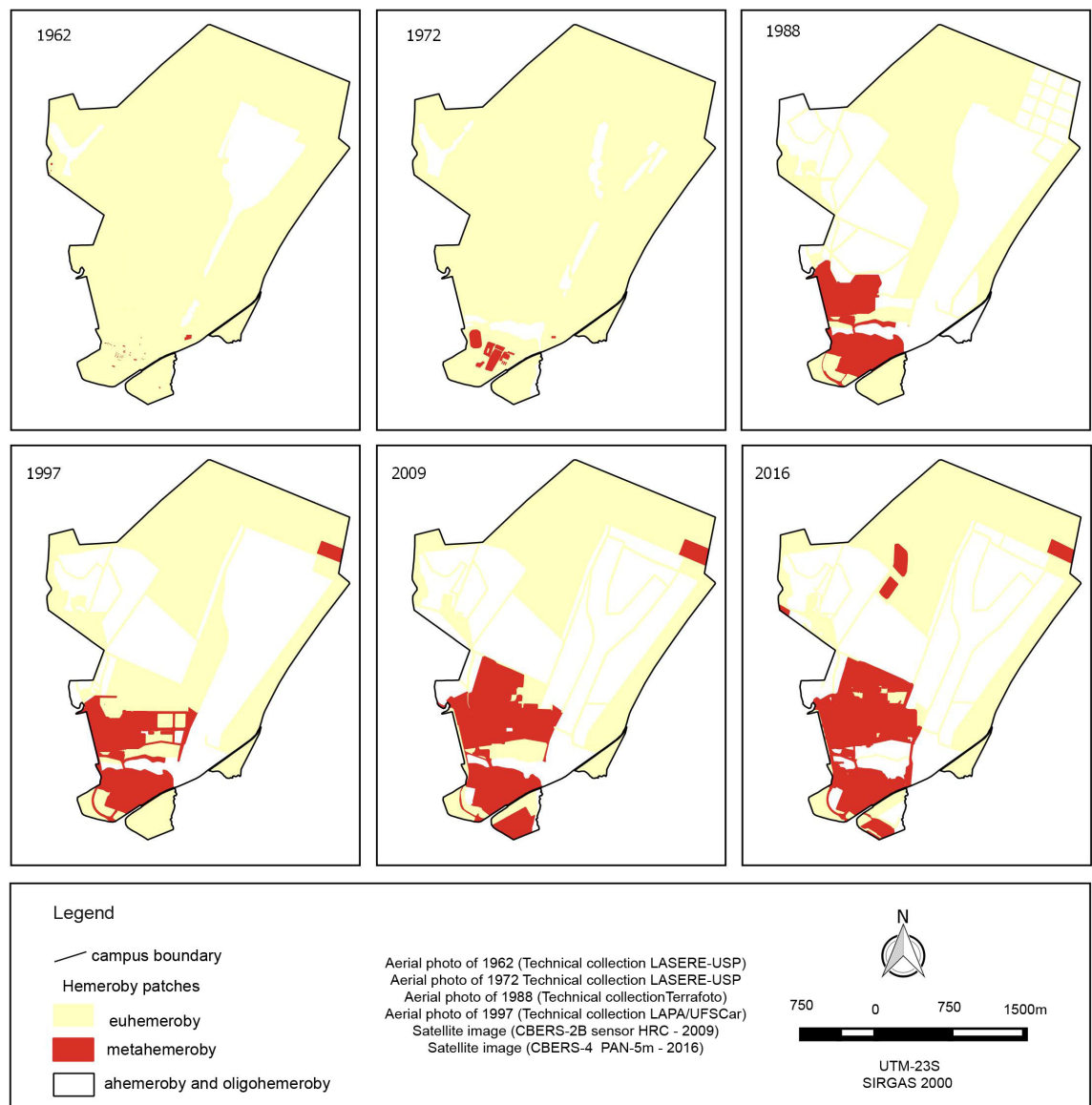

Figure 5. Sequence of anthropogenic influence of campus landscape dynamics related to euhemerob to metahemerob patches transition resulting from UFSCar campus landscape urbanization, since 1972, over a 54-year period (1962-2016).

ous with its configuration characterized by complex patches shapes, by a large variability of patches sizes and shapes, and by a high frequency of edge habitat. Each hemerobiotic state is consequently composed of one or more patches or landscape elements, corresponding to a homogeneous area (Figure 6).

The ahemerob patch type dominating the campus landscape is characterized by the lowest degree of fragmentation and the largest area, in 2016. Ahemerob patches and the species they support in campus landscape is currently embedded within anthropogenic mosaics of land use/cover. However, evidence of increased metahemerob patches, which advanced over time by urbanization, replacing euhemerob patches, is expected to homogenize campus landscape pattern (Figure 6; Table 1).

Thus a campus landscape dynamics model, which can be denoted as "forestry-conservation-urban model", anthropogenic landscape are replaced by natural one, and later by land cover reflecting urban development. The determinants that conditioned the campus landscape spatial pattern in 2016 (Figure 6) are more relevant in proposing future scenarios than those that operated 30 years ago. 


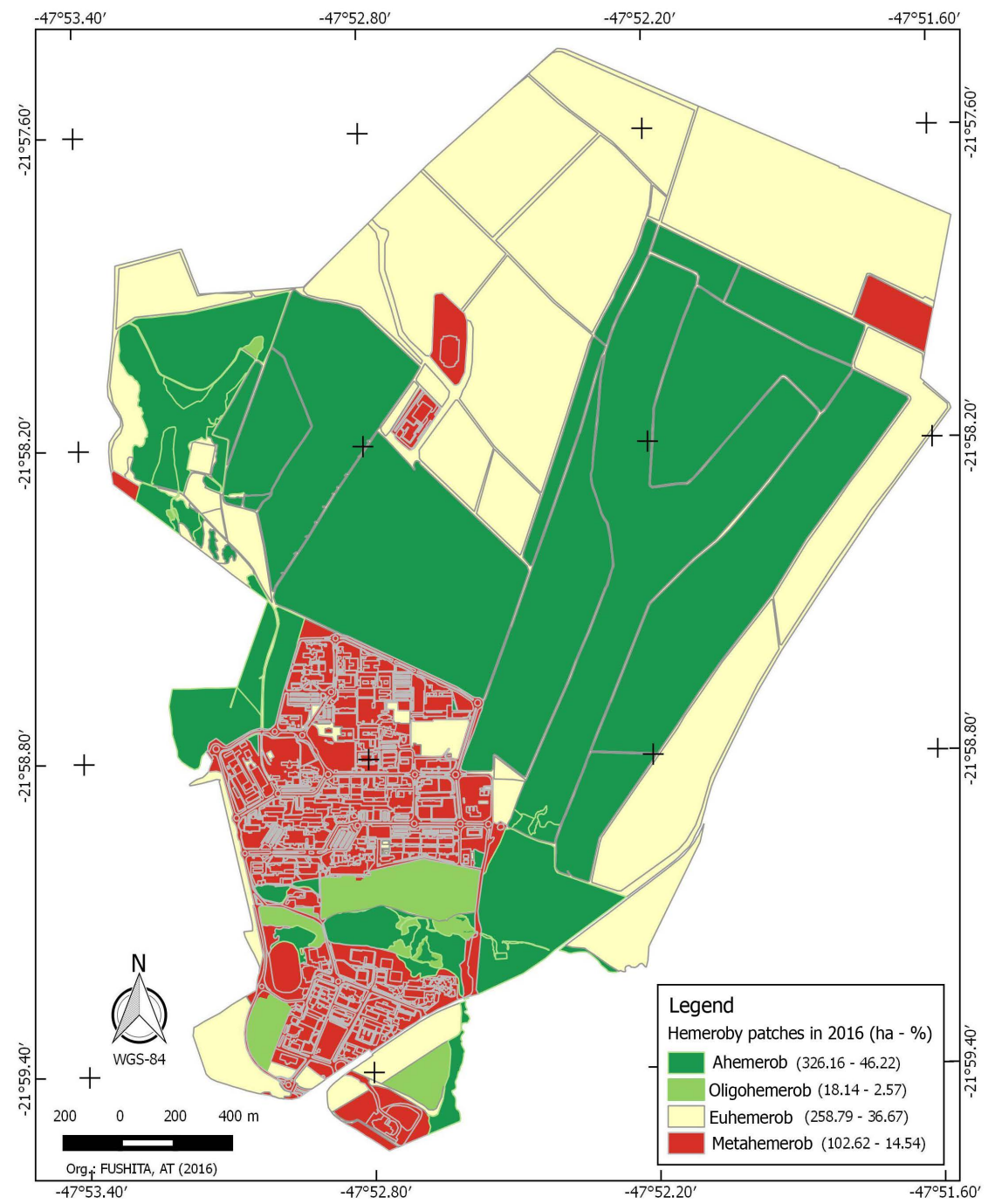

Figure 6. Spatial campus landscape configuration of hemeroby patches and respective areas (ha/\%) of the Federal University of São Carlos (São Carlos, SP), for 2016.

Consequently, prognosis related to the expansion and establishment of a progressive metahemerob spatial pattern, for next decades, must comply in defining an optimal configuration and amount between natural (ahemerob and oligohemerob) and anthropic (euhemerob and metahemerob) land use; i.e., to enable a balance between conservation and urbanization. The critical threshold for urbanization expansion on the campus landscape, referred to as anthropisation process, must be limited by available euhemerob patches area (forestry area), from 2016 (Figure 7).

The modification of UFSCar campus landscape by human action will lead to anthropogenic landscape, over time, in which man-made features dominate, and to a positive reinforcement of natural land cover in campus landscape. Otherwise ahemeroby patch types will be threatened and reduced to a scattered pattern.

The main institutional challenge for campus landscape sustainable manage- 


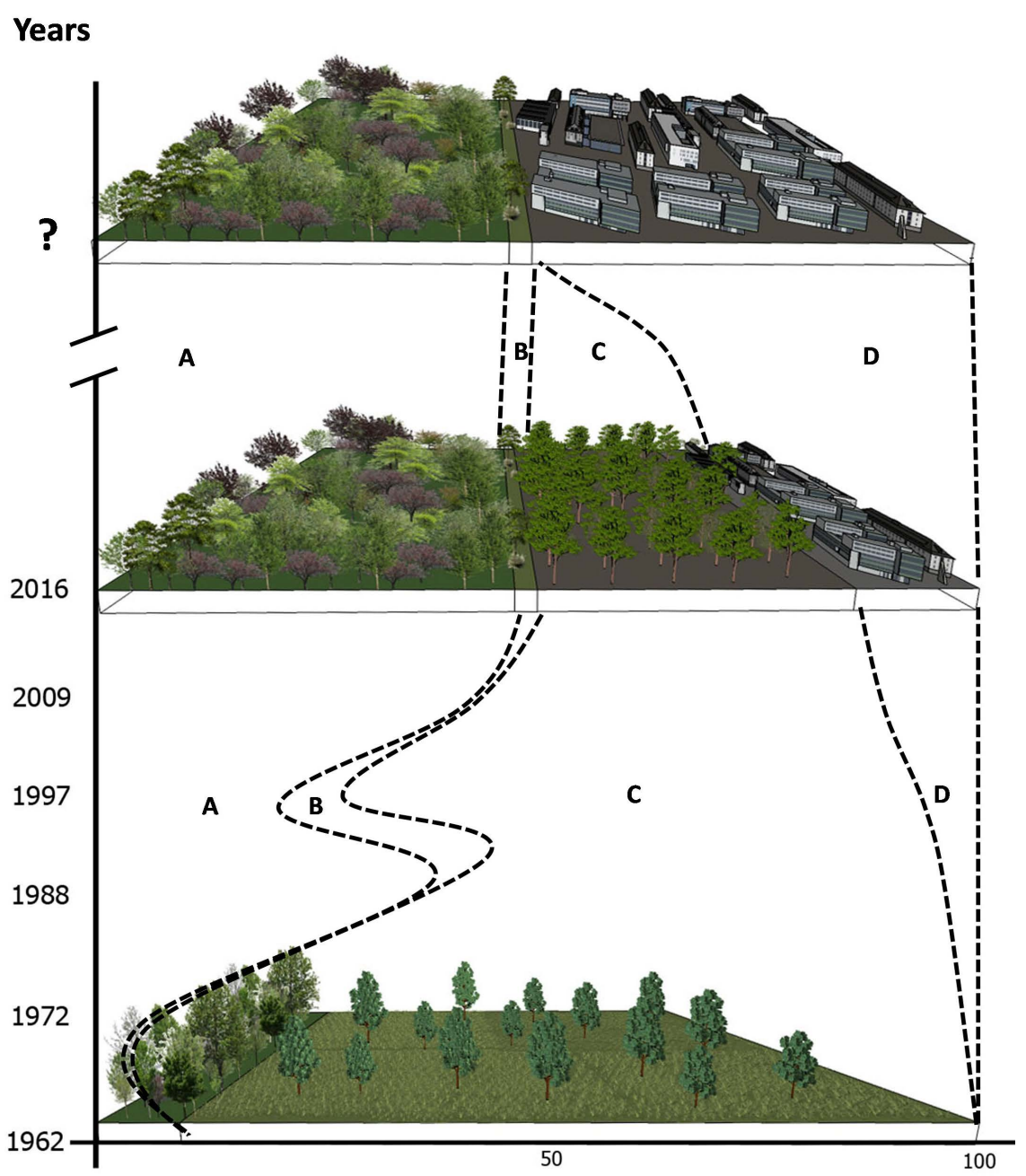

\begin{tabular}{|c|c|c|c|c|c|c|}
\hline \multirow{2}{*}{ 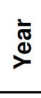 } & \multirow[b]{2}{*}{ Area } & \multicolumn{5}{|c|}{ Hemeroby level types } \\
\hline & & \begin{tabular}{|c|}
$\begin{array}{c}\text { Ahemerob } \\
\text { (A) }\end{array}$ \\
\end{tabular} & $\begin{array}{l}\text { Oligohemerob } \\
\text { (B) }\end{array}$ & $\begin{array}{l}\text { Euhemerob } \\
\text { (C) }\end{array}$ & $\begin{array}{l}\text { Metahemerob } \\
\text { (D) }\end{array}$ & Total \\
\hline \multirow{2}{*}{ ণั } & ha & 68.91 & 2.88 & 633.19 & 0.73 & 705.71 \\
\hline & $\%$ & 9.76 & 0.41 & 89.72 & 0.10 & 100.00 \\
\hline \multirow{2}{*}{ ลั } & ha & 326.16 & 18.14 & 258.79 & 102.62 & 705.71 \\
\hline & $\%$ & 46.22 & 2.57 & 36.67 & 14.54 & 100.00 \\
\hline
\end{tabular}

Figure 7. Sequence of the hemerobiotic states area values (ha/\%) of campus landscape dynamics, over a 54-year period (1962-2016). The figure points out the institutional challenge of considering the time in which the critical threshold of urbanization, represented by metahemerob patches (D), with the total occupation of euhemerob patches (C), can ensure the continuity and quantity of the ahemerob patches (A), in terms of the amount of biodiversity that should be conserved for utilitarian reasons because of its role in providing and sustaining ecosystem services.

ment lies in the balance between the competitors of the campus landscape matrix: conservation (ahemerob patches area/46\%) $\times$ urbanization (euhemerob/ metahemerob patches area/51\%). To ensure a critical threshold of ahemerob patches area, from 2016, which represents the level of campus landscape biodi- 
versity (Figure 7).

The question marks indicate the uncertainties about the appropriate size of amount of biodiversity, over time, that should be conserved: 1) for utilitarian reasons because of its role in providing and sustaining ecosystem services, 2) for non-utilitarian values such as intrinsic values, and 3) for utilitarian reasons because of its role in maintaining capacity to adapt to change (resilience), and for option and existence values.

The critical threshold of urbanization increase in campus landscape should be valid for a period without uncertainties regarding political and socioeconomic scenery of the country. That is, the availability of resources and financial support to enable the expansion and operation of campus infrastructure that serves a growing social component over time.

The social component of the campus landscape (teachers, technical and administrative staff, students, decision makers, and external community) has, fundamentally, different local standards to evidence human influence on biodiversity and ecosystem processes in the campus landscape, over the 54-year period. Since an intrinsic reciprocal relationship between culture and landscape structure exists: culture changes landscapes and culture is embodied by landscape [37], relationship between biological diversity and social component contribute for 2016's hemeroby spatial pattern across campus landscape.

\section{Conclusions}

These results reveal what is happening with the campus landscape configuration, over the 54-year period. But that is just part of the history.

We are always very interested in knowing the historical trajectory of the UFSCar campus landscape, because changes that occurred in the near past are more relevant than those that occurred in the more remote past, in determining the current spatial pattern of the campus landscape.

Our results illustrate the potential utility of assessing how specific trajectories of past land cover changes have influenced hemeroby patterns in the present, within the context of developing sustainable campus landscape management strategies that minimize loss of biodiversity.

\section{Acknowledgements}

LASERE-USP Technical Colletion for providingaerial photos

\section{References}

[1] Urban, D.L., O’Neill, R.V. and Shugart Jr., H.H. (1987) Landscape Ecology. A Hierarquical Perspective Can Help Scientists Understand Spatial Patterns. Bioscience, 37, 119-127. https://doi.org/10.2307/1310366

[2] Forman, R.T.T. (1995) Land Mosaics. The Ecology of Landscapes and Regions. Cambridge University Press, Cambridge.

[3] Bogaert, J. and Mahamane, A. (2005) Ecology of the Landscape: Targeting the Configuration AND Spatial Scale. Annales des Sciences Agronomique, 7, 1-15. 
[4] Forman, R.T.T. and Godron, M. (1986) Landscape Ecology. Wiley, New York.

[5] Hobbs, R.J. (2002) The Ecological Context: A Landscape Perspective. Handbook of Ecological Restoration: Principles of Restoration, 24-46. https://doi.org/10.1017/CBO9780511549984.005

[6] Gustafson, E.J. and Diaz, N. (2002) Landscape Pattern, Timber Extraction, and Biological Conservation. In: Applying Landscape Ecology in Biological Conservation, Springer, New York, 244-265. https://doi.org/10.1007/978-1-4613-0059-5_14

[7] Collinge, S.K. (1998) Spatial Arrangement of Habitat Patches and Corridors: Clues from Ecological Field Experiments. Landscape and Urban Planning, 42, 157-168. https://doi.org/10.1016/S0169-2046(98)00085-1

[8] Farina A. (2000) The Cultural Landscape as a Model for the Integration of Ecology and Economics. BioScience, 50, 313-320. https://doi.org/10.1641/0006-3568(2000)050[0313:TCLAAM]2.3.CO;2

[9] Sanderson, E.W., Redford, K.H., Vedder, A., Coppolillo, P.B. and Ward, S.E. (2002) A Conceptual Model for Conservation Planning Based on Landscape Species Requirements. Landscape and urban planning, 58, 41-56. https://doi.org/10.1016/S0169-2046(01)00231-6

[10] Ellis, E.C. and Ramankutty, N. (2008) Putting People in the Map: Anthropogenic Biomes of the World. Frontiers in Ecology and the Environment, 6, 439-447. https://doi.org/10.1890/070062

[11] Bogaert, J., Vranken, I. and André, M. (2014) Anthropogenic Effects in Landscapes: Historical Context and Spatial Pattern. In: Hong, S.K., Bogaert, J. and Min, Q., Eds., Biocultural Landscapes. Diversity, Functions and Values, Springer, The Netherlands, 89-112. https://doi.org/10.1007/978-94-017-8941-7_8

[12] Bogaert, J., Barima, Y.S.S., Ji, J., Jiang, H., Bamba, I., Mongo, L.I.W. and Koedam, N. (2011) A Methodological Framework to Quantify Anthropogenic Effects on Landscape Patterns. In: Hong, S.K., et al., Eds., Landscape Ecology in Asian Cultures, Springer, Japan, 141-167. https://doi.org/10.1007/978-4-431-87799-8_11

[13] O’Neill, R.V., Krummel, J.R., Gardner, R.H., et al. (1988) Indices of Landscape Pattern. Landscape Ecology, 3, 153-162. https://doi.org/10.1007/BF00162741

[14] Wiens, J.A., Stenseth, N.C., Horne, B. and Van, R.A. (1993) Ecological Mechanisms and Landscape Ecology. Oikos, 66, 369-380. https://doi.org/10.2307/3544931

[15] Turner II, B.L., Kasperson, R.E., Matsone, P.A., et al. (2003) A Framework for Vulnerability Analysis in Sustainability. Science: PNAS, 100, 8074-8079. https://doi.org/10.1073/pnas.1231335100

[16] Haberl, H., Wackernagel, M. and Wrbka, T. (2004) Land Use and Sustainability Indicators. An Introduction. Land Use Policy, 21, 193-198.

https://doi.org/10.1016/j.landusepol.2003.10.004

[17] Wrbka, T., Erb, K.H., Schulz, N.B., Peterseil, J., Hahn, C. and Haberl, H. (2004) Linking Pattern and Process in Cultural Landscapes. An Empirical Study Based on Spatially Explicit Indicators. Land Use Policy, 21, 289-306. https://doi.org/10.1016/j.landusepol.2003.10.012

[18] Rüdisser, J., Tasser, E. and Tappeiner, U. (2012) Distance to Nature. A New Biodiversity Relevant Environmental Indicator Set at the Landscape Level. Ecological Indicators, 15, 208-216. https://doi.org/10.1016/j.ecolind.2011.09.027

[19] Jalas J. (1955) Hemeroby and Hemerochore of Plant Species. A Terminological Reform Effort. Acta Societatis pro Fauna et Flora Fennica, 72, 1.

[20] Sukopp, H. (1969) The Influence of Man on the Vegetation. Vegetatio, 17, 360-371. 
https://doi.org/10.1007/BF01965917

[21] Olak, A.H.C., Rotherham, I.D. and Alikoglu, C. (2003) Combining 'Naturalness Concepts' with Close-to-Nature Silviculture. Forstwissenschaftliches Centralblatt, 122, 421-431. https://doi.org/10.1007/s10342-003-0007-1

[22] Anderson, J.E. (1991) A Conceptual Framework for Evaluating and Quantifying Naturalness. Conservation Biology, 5, 347-352. https://doi.org/10.1111/j.1523-1739.1991.tb00148.x

[23] Knight, R.L. and Landres, P.B. (2002) Central Concepts and Issues of Biological Conservation. In: Gutzwiller, K.J., Ed., Applying Landscape Ecology in Biological Conservation, Springer Science \& Business Media, Berlin, Heidelberg, 22-34. https://doi.org/10.1007/978-1-4613-0059-5_2

[24] Siipi, H. (2004) Naturalness in Biological Conservation. Journal of Agricultural and Environmental Ethics, 17, 457-477. https://doi.org/10.1007/s10806-004-1466-1

[25] Reif, A. and Walentowski, H. (2008) The Assessment of Naturalness and Its Role for Nature Conservation and Forestry in Europe. Waldökologie Online, 6, 63-76.

[26] McRoberts, R.E., Winter, S., Chirici, G. and LaPoint, E. (2012) Assessing Forest Naturalness. Forest Science, 58, 294-309. https://doi.org/10.5849/forsci.10-075

[27] Winter, S. (2012) Forest Naturalness Assessment as a Component of Biodiversity Monitoring and Conservation Management. Forestry, 85, 293-304. https://doi.org/10.1093/forestry/cps004

[28] Hill, M.O., Roy, D.B. and Thompson, K. (2002) Hemeroby, Urbanity and Ruderality: Bioindicators of Disturbance and Human Impact. Journal of Applied Ecology, 39, 708-720. https://doi.org/10.1046/j.1365-2664.2002.00746.x

[29] Kiedrzyński, M., Kiedrzyńska, E., Witosławski, P., Urbaniak, M. and Kurowski, J.K. (2014) Historical Land Use, Actual Vegetation, and the Hemeroby Levels in Ecological Evaluation of an Urban River Valley in Perspective of Its Rehabilitation Plan. Polish Journal of Environmental Studies, 23, 109-117.

[30] Santa Barbara, Â.D.L., Valaski, S. and Nucci, J.C. (2014) Hemeroby and Landscape Planning in Mossunguê Neighborhood, Curitiba-PR. Geografar Journal, 9, 159-179. https://doi.org/10.5380/geografar.v9i1.36540

[31] Sguissardi, V. (1993) University, Foundation and Authoritarianism: The Case of UFSCar. EDUFSCar, São Carlos.

[32] Crosta, A.P. (1992) Digital Processing of a Remote Sensing Image. 3rd Edition, IG/UNICAMP, Campinas.

[33] Moreira, M.A. (2011) Remote Sensing Fundaments and Application Methods. 4th Edition, UFV, Viçosa, Brasil.

[34] Haber, W. (1994) System Ecological Concepts for Environmental Planning. In: Klijn, F., Ed., Ecosystem Classification for Environmental Management, Springer, The Netherlands, 49-67. https://doi.org/10.1007/978-94-017-1384-9_3

[35] IBGE-Brazilian Institute of Geography and Statistics (2013) Land Use Technical Guide. 3rd Edition, IBGE, Rio de Janeiro.

[36] Testi, A.G.R.V.D., Fanelli, G., et al. (2012) Characterizing River Habitat Quality Using Plant and Animal Bioindicators: A Case Study of Tirino River (Abruzzo Region, Central Italy). Ecological Indicators, 20, 24-33. https://doi.org/10.1016/j.ecolind.2012.01.027

[37] Nassauer, J.I. (1995) Culture and Changing Landscape Structure. Landscape Ecology, 10, 229-237. https://doi.org/10.1007/BF00129257 